\title{
Fatigue Durability of Ductile Iron in Very-High-Cycle Region
}

František Nový1, Peter Kopas ${ }^{1}$, Otakar Bokůvka ${ }^{1}$, Adriana Savin ${ }^{2}$

${ }^{1}$ Faculty of Mechanical Engineering, University of Žilina, Univerzitná 1, 01026 Žilina, Slovak Republic. E-mail: frantisek.novy@fstroj.uniza.sk, peter.kopas@fstroj.uniza.sk, otakar.bokuvka@fstroj.uniza.sk

${ }^{2}$ National Institute of R\&D for Technical Physics, Mangeron Boulevard 47, 700050 Iasi, Romania. E-mail: asavin@physiasi.ro

In this work there are published results about fatigue resistance of ductile iron with various types of matrix obtained at cyclic loading in very-high-cycle region. The results show continuous decrease of the stress amplitude with increasing of cycles number to the failure. The tensile strength increase is not accompanied with corresponding increase of fatigue properties. The fatigue durability decreases while the tensile strength increases.

Keywords: Ductile iron, austempered ductile iron, fatigue durability

\section{Acknowledgement}

This research has been partially supported by Scientific Grand Agency of Ministry of Education of Slovak Republic and Slovak Academy of Sciences, grants VEGA No. 1/0123/15 and 1/0683. A part of research was solved also in the frame of the European Regional Development Fund and Slovak State Budge project APVV-14-0096. This support is gratefully acknowledged.

\section{References}

[1] ULEWICZ, R. (2014). Practical application of quality tools in the cast iron foundry. In: Manufacturing Technology, Vol. 14, No. 1, p. 104-111.

[2] KOVACS, B. V. (1994). AFS Trans., p. 102.

[3] DAVENPORT, E., BAIN, E. (1930) Transformation of austenite at constant sub-critical temperatures. In: Trans Am. Inst. Mining Metallurg. Eng., Iron and Steel Division, p. 117.

[4] VAŠKO, A. (2013). Influence of the heat treatment on the microstructure of synthetic nodular cast irons. In: Manufacturing Technology, Vol. 13, No. 1, p. 115-119.

[5] BATHIAS, C., PARIS, B. C. (2005). Gigacycle Fatigue in Mechanical Practice, M. Dekker, New York.

[6] NOVÝ, F., ČINČALA, M., KOPAS, P., BOKU゚VKA, O. (2007) Mechanisms of high-strength structural materials fatigue failure in ultra-wide life region. In: Materials Science and Engineering A, Vol. 462, No. 1-2, p. 189-192.

[7] KUNZ, L., FINTOVÁ, S. (2014). Fatigue behaviour of AZ91 magnesium alloy in as-cast and severe plastic deformed conditions. Advanced Materials Research, Vol. 891-892, p. 397-402.

[8] NOVÝ, F., TRŠKO, L., ULEWICZ, R., DUNDEKOVÁ, S. (2015). Influence of electrodeposited coatings on ultra-high-cycle fatigue life of S235 structural steel. In: Materials Science Forum, Vol. 818, p. 37-40.

[9] KONEČNÁ, R., NICOLETTO, G., BUBENKO, L., FINTOVÁ, S. (2013). A comparative study of the fatigue behavior of two heat-treated nodular cast irons. In: Engineering Fracture Mechanics, Vol. 108, p. 251-268.

[10]ULEWICZ, R., NOVÝ, F., SELEJDAK, J. (2014). Fatigue strength of ductile iron in ultra-high cycle regime. In: Advanced Materials Research, Vol. 874, p. 43-48.

[11]BOKU゚VKA, O., NICOLETTO, G., GUAGLIANO, M., KUNZ, L., PALČEK, P., NOVÝ, F., CHALUPOVÁ, M. (2015). Low and High - Frequency Fatigue Testing, EDIS ŽU Žilina, Žilina, p. 98-139.

[12]PUŠKÁR, A. (1997). Vysokofrekvenčná únava materiálov, EDIS ŽU Žilina, Žilina, p.162-198. (in Slovak).

[13]HADZIMA, B., SUCHÝ, P. (2007). Krátkodobá pasivácia povrchu ocele WNr. 1.7139. In: Materials Engineering, Vol. 14, No. 4, p. 31-34. (in Slovak).

[14]VĚCHET, S., KOHOUT, J., BOKŮVKA, O. (2001). Únavové vlastnosti tvárné litiny, EDIS ŽU Žilina, Žilina, p. 21-85. (in Czech).

[15]VĚCHET, S., KOHOUT, J., HANZLÍKOVÁ, K. (2005). Influence of isothermal transformation dwell on tensile and fatigue properties of austempered ductile cast iron. In: Materials Science Forum, Vol. 482, p. 371-374. 
[16]VAŠKO, A., TRŠKO, L., KONEČNÁ, R. (2015). Fatigue behaviour of synthetic noduar cast irons. In: Metalurgija, Vol. 54, No. 1, p. 19-22.

[17]NOVÝ, F., BOKU゚VKA, O., KOPAS, P., CHALUPOVÁ, M. (2007). Fatigue endurance of nodular cast iron in gigacycle region. In: Proceedings of the Improvement of quality regarding processes and materials (S. Borkowski (Ed.)), ORGMASZ Warszawa, p. 71-74.

[18]ULEWICZ, R., BORKOWSKI, S. (2004). Fatigue crack in ferrite-pearlite nodular cast iron at loading with very high frequencies. In: Proceedings of the Letná škola únavy materiálov 2004 (O. Bokůvka (Ed.)), Vol. 7, EDIS ŽU, Žilina, p. 203-206.

[19]KOPAS, P., NOVÝ, F. (2005). Ductile iron and austempered ductile iron in engineering praxis. In: Proceedings of the Jakość w inżynierii materiałowej i usługach (S. Borkowski (Ed.)), ORGMASZ Warszawa, p. 14-17.

[20]HURTÁlOVÁ, L., TILlOVÁ, E., BELAN, J., UHRIČÍK. M., VAŠKO, A., CHALUPOVÁ, M. (2015). Influence of microshrinkage defects on the fatigue properties in AlSi9Cu3 casts. In: Proceedings of the International conference on innovative technologies IN-TECH 2015 (Z. Car and J. Kudláček (Eds.)), Faculty of Engineering University of Rijeka, Dubrovnik, p. 69-72.

Copyright (C) 2016. Published by Manufacturing Technology. All rights reserved. 